\title{
REIMAGINING DIRECT DEMOCRACY AS AN INTERSECTION OF DIFFERENT FORMS OF REPRESENTATION
}

\begin{abstract}
As an exceptional device in the life of contemporary constitutional democracies, direct democracy is normally considered to be separate from representation. In this paper, I explore this well-established divide, asking how it interacts with our understanding of the central subject of direct democracy, the people. I show how theorizing that takes its cue from the dichotomy between "absence" and "presence", ascribed to the separation of representation and forms of direct democracy, is tied with identifying the active electorate and the people. On the other hand, this approach is inept for comprehending the ways representations of the people are produced and instrumentalized in the wake of direct democracy. In this paper, I suggest that this phenomenon may be approached by examining how direct democracy is entangled with representing "the people" through arguments, processes and constructs.
\end{abstract}

Key words: direct democracy, referendum, representative democracy, representation, constitutional theory.

\section{INTRODUCTION}

Direct democracy has enjoyed a renewed attention in the quarters of constitutional theory, most notably with respect to constitutional amendments. ${ }^{1}$ Despite the increased interest, however, the notion of direct democracy itself remains undertheorized. Its forms are primarily conceptualized as endpoints to political controversies that allow the electorate to have their say on a specific matter. In constitutional theory, then, direct democracy is identified as an absence of representation and the ostensible presence

* Junior Faculty Member, University of Rijeka - Faculty of Law

e-mail: mmilos@pravri.hr

1 Colón-Ríos, J. I., 2012, Weak Constitutionalism. Democratic Legitimacy and the Question of Constituent Power, New York, Routledge; Tierney, S., 2012, Constitutional Referendums: The Theory and Practice of Republican Deliberation, Oxford, Oxford University Press; Contiades, X., Fotiadou, A. (eds.), 2016, Participatory Constitutional Change. The People as Amenders of the Constitution, Routledge, New York. 
of "the people". What remains is to encase the act of voting in procedures ensuring that the electorate will be as informed and as engaged as possible for the outcome of direct democracy to be both lawful and legitimate. ${ }^{3}$ The law is a technical means to ensuring "democracy and liberty".

Constitutional theory mirrors a dominant approach in political science, which identifies "popular vote processes", such as referendums, with direct democracy and opposes the latter to representation. ${ }^{5}$ Thus, a constitutional law scholar may study the law on direct democracy with the assumption that its various forms, such as referendums, are discrete phenomena that may be understood in isolation from representation. ${ }^{6}$ The fact that the law establishes forms of direct democracy as more or less distinct entities seems to lend force to this view.

"The people" are at the core of the imagined divide between representation and direct democracy, as it is their placement in relation to political power that determines whether a form of direct democracy displaces representation. According to the existing literature, there is more to it than citizens voting on a specific question. In a treatment of the issue, Tierney notes that democracy may not be considered properly "direct" if it does not create a radical break with the existing representative system, making a successful referendum on self-determination a paradigmatic example of true direct democracy. ${ }^{7}$ Hence, Tierney argues that it is the impact of the vote, rather than the vote itself, that counts for the political

2 For instance, Schmitt describes direct democracy as "unmediated" or "pure" democracy. (Schmitt, C., 2014, Volksentscheid und Volksbegehren. Ein Beitrag zur Auslegung der Weimarer Verfassung und zur Lehre von der unmittelbaren Demokratie, Berlin, Duncker \& Humblot, p. 9.) In contemporary theory, Suksi draws a difference between "pure" and "direct" democracy, arguing that, given that contemporary forms of direct democracy do not involve citizens actually meeting and deliberating in a "face to face setting", they cannot be considered a kind of "pure" democracy. (Suksi, M., 1993, Bringing in the People. A Comparison of Constitutional Forms and Practices of the Referendum, Dordrecht, Martinus Nijhoff Publishers, p. 5.) Nonetheless, Suksi opposes the "presence" of the people in direct democracy to their "absence" in representation. (Suksi, M., 1993, pp. 18-19)

3 In terms of constitutional referendums, Tierney's treatise is unsurpassed in the field. (Tierney, S., 2012)

4 Morel, L., Referendum, in: Rosenfeld, M., Sajó, A. (eds.), 2012, The Oxford Handbook of Comparative Constitutional Law, Oxford, Oxford University Press, p. 527.

5 El-Wakil, Alice, McKay, S., 2019, Disentangling Referendums and Direct Democracy: A Defence of the Systematic Approach to Popular Vote Processes, Representation Journal of Representative Democracy, (https://www.tandfonline.com/doi/full/10.1080/ 00344893.2019.1652203).

6 See, for instance, Noyes, H., 2014, The Law of Direct Democracy, Durham, Carolina Academic Press.

7 Tierney, S., 2012, p. 55. 
"presence" of the people. This also suggests, however, that other forms of direct democracy may be understood as forms of representation, rather than being an expression of unmediated rule, and as such may be considered of a different significance. Furthermore, even if an act of direct democracy is taken to be a break with the existing representative system, it is only to inaugurate a new representative system following the self-determination.

There is thus a nexus between representation and direct democracy that requires closer attention, as it is through claims of "direct rule" by the people that particular political paths are reinforced and alternatives to them marginalized or abolished. ${ }^{8}$ Here I want to take a step towards this larger project. I suggest that, when the absence of representation and presence of the electorate define the meaning of "direct democracy" in contemporary constitutional theory, the representative work involved in producing "the people" becomes lost. By consequence, as I will argue, "the people" in direct democracy is regularly seen as an active and, for the most part, exceptional subject. In this paper, I argue that this understanding is lopsided. Rather than being a project of enabling the input of active citizenry, where the law is seen as a tool for facilitating the empowered electorate, ${ }^{9}$ to regulate and practice contemporary direct democracy involves the articulation of fora for representing "the people". The law frames these and they both mediate and are produced through direct democracy. In the process, the electorate is not only active in episodic and self-referential decision-making but is a party in reshaping the political spaces and the ways in which "the people" may be made manifest. At issue then is not only who the people are, a matter already raised by scholars, ${ }^{10}$ but how they may politically be. There is thus good cause for constitutional theorists to study representation as an integral element of contemporary direct democracy. To do so is to bring to light how acts of direct democracy may be seen as struggles over different understandings of the people and its political place, rather than the result of a binary choice between "direct" and "indirect" decision-making.

In this paper, I first argue that contemporary constitutional theory examines direct democracy from a narrowed perspective, locating the

8 Brexit is at the time of writing still the perfect case in point. (Reeves, M., 2016, Democracy on speed, Social Anthropology, Vol. 24, No. 4, p. 479)

9 Tierney, S., The Scottish Independence Referendum: A Model of Good Practice in Direct Democracy?, in: Ruth-Lovell, S. P., Welp, Y., Whitehead, L. (eds.), 2017, Let the People Rule? Direct Democracy in the Twenty-First Century, Colchester, ECPR Press, p. 78.

10 Oklopcic, Z., 2012, Independence Referendums and Democratic Theory in Quebec and Montenegro, Nationalism and Ethnic Politics, Vol. 18, No. 1, p. 22. 
specificity of direct democracy in the popular vote. In doing so, it identifies "the people" with an episodically active electorate and leaves to the wayside the mediation required to make direct democracy possible. Direct democracy, in this light, is in itself empty. (2.) I then illustrate how this picture is incomplete. Direct democracy necessarily implicates representation in raising the qualities of the political existence of the people and representation may thus be seen as its content. (3.) In the final part of the paper, I suggest that a more holistic approach to forms of direct democracy in constitutional theory should not be based on a fixation with the voting electorate. Instead, it should acknowledge that direct democracy may challenge or reinforce different sites of representation and that it is in this sense a plurality of representations, rather than their exclusion, that should form an important aspect of direct democracy as a category in constitutional theory. This alternative perspective may be approached, I suggest, by differentiating representation as a process, argument and construct. (4.)

\section{Direct Democracy and the People: Voting, Mediation, Representation}

In constitutional theory, direct democracy as a concept is normally not differentiated from direct democracy as a practice. Thus, direct democracy is considered to be an umbrella term for all political processes in which the citizenry may exercise their right to vote to suggest or reach a decision on a sufficiently defined matter. ${ }^{11}$ While it is acknowledged that these processes must necessarily be regulated by law in order to function well, the most sophisticated accounts argue for enabling a well-informed electorate and reducing the possibility of abuse of the process to a minimum. ${ }^{12}$ Direct democracy is thus taken to be a specific unit that needs to be regulated accordingly.

11 Take, for instance, Hamon's comprehensive overview of different classifications of direct democracy. (Hamon, F., 2012, Le referendum. Étude comparative, Paris, L.G.D.J.) See also Suksi, M., 1993.

12 Tierney, S., 2012. Two main forms of direct democracy may be differentiated, referendums and citizens' initiative. The two will not be discussed separately in this piece, as the arguments developed here may be applied to both. The chief difference that may be drawn between referendums and citizens' initiatives lies in the degree of agency accorded to the electorate. In referendums initiated by the parliament or the executive, the electorate can only accept or reject the suggested decision. In citizens' initiatives, an organized group within the electorate can formulate the topic that calls for a decision, but these procedures do not necessarily lead to a referendum. In some jurisdictions, initiatives may be decided by the parliament, which is the case in Spain, 
This approach to direct democracy may be justified insofar as it is sensitive to the need to preserve its forms as the means to realize popular sovereignty. After all, as Möllers argues, constitutional theory cannot be so ambitious in its scope that it seeks to completely dominate and control political decision-making. ${ }^{13}$ Such an overreach would undoubtedly occur if the theorist developing an autonomous concept of direct democracy denied the real-life use of the practice as a legitimate ingredient of a democracy. Additionally, the law is in any case not able to exhaustively regulate and make predictable all instances of direct democracy. ${ }^{14}$

Having said this, a simplistic reception of "direct democracy" as a group of well-known procedures, such as referendums and citizens' initiatives, also has its consequences. Most importantly, it weds the theorist to a single and simplified image of the central subject of the procedures, "the people". This is because the key empirical specificity of direct democracy is the act of voting, even though it is not argued that this is enough for an acceptable outcome of the procedure. ${ }^{15}$ If direct democracy is distinct because, rather than the representatives, it is the electorate that votes, "the people" is effectively identified precisely with the electorate that necessarily exists in the "here and now", the democratic present. ${ }^{16}$ Its interaction with other visions of itself, most notably that formed in representative democracy, possibly becomes downplayed. This is particularly problematic insofar as forms of direct democracy become associated with a wellknown theoretical category, the constituent power (pouvoir constituant), as it is then the electorate that disposes with "an originative and extralegal power to create and remake a constitution" 17 and, with it, the power to suppress alternative visions of "the people".

or a referendum may be prevented if the parliament adopts the suggestion contained in the initiative, which was the case in Croatia. While at first glance citizens' initiatives allow for greater political input of the electorate, it is only an organised minority that can access the procedure, with the broader electorate playing only a reactive role, and then only if the referendum occurs.

13 Möllers, C., 2012, Les Gardiennes d'une séparation: les constitutions comme instruments de protection des différences entre le droit et la politique, Jus politicum, Vol. 7, No. 1, p. 7.

14 Daly, E., 2020, Constitutionalism and crisis narratives in post-Brexit politics, Political Studies, (https://doi.org/10.1177/0032321720904936m), p. 6.

15 Trueblood, L., The Uses and Abuses of Referendums, doctoral thesis, University of Oxford - Trinity College, (https://ethos.bl.uk/OrderDetails.do?uin=uk.bl.ethos.770425), p. 66.

16 Linz, J., 1998, Democracy's Time Constraints, International Political Science Review, Vol. 19, No. 1, p. 27.

17 Daly, E., 2019, Translating Popular Sovereignty and Unfettered Constitutional Amendability, European Constitutional Law Review, Vol. 15, No. 4, p. 620. 
Secondly, by defining direct democracy only based on the popular vote, constitutional theory fails to systematically examine how direct democracy is a legal and political construct. As Daly rightfully notes, direct democracy hinges on forms of mediation that make it possible. ${ }^{18}$ These are not necessarily restricted to a national legal and political order, but may stem from beyond its boundaries, even affecting the status of an act of direct democracy as an expression of pouvoir constituant. ${ }^{19}$ These different mediating factors, both coming from within and without, may be divided into three groups: institutional, structural and ideational.

As far as institutional structures are concerned, not only is direct democracy always an answer to a question that is asked by someone beyond "the people", ${ }^{20}$ be it a group of voters in a citizens' initiative, the parliament or the executive, but the enforcement of the decision always rests upon an authority not synonymous with the electorate. ${ }^{21}$ The openness of direct democracy processes to interference is furthered by the similarity of its forms to elections, which in some jurisdictions allowed political parties to have a powerful impact on their course. ${ }^{22}$

In addition to these, there are structural mediations upon which forms of direct democracy depend. Indeed, the very question that is placed before the electorate is one such structure, allowing the citizenry to gather in a metaphorical space created by the topic of the decision-making process. The majority they will thus form is another mediating structure, a construct separate from the voters themselves, formed out of their anonymous votes, ${ }^{23}$ which in some jurisdictions may only be effective if it meets predetermined thresholds of participation or approval. ${ }^{24}$ Finally, the law itself is a mediating factor in a structural sense, not only because it

18 Daly, E., 2019, pp. 1, 11-12; Daly, E., 2020, p. 6.

19 Oklopcic, Z., 2012, Constitutional (Re)Vision: Sovereign Peoples, New Constituent Powers, and the Formation of Constitutional Orders in the Balkans, Constellations, Vol. 19, No. 1, p. 91.

20 Krbek, I., Repräsentation nach der Doktrin der Volkssouveränität, in: Bracher, K. D. et al. (eds.), 1966, Die moderne Demokratie und ihr Recht. Festschrift für Gerhard Leibholz zum 65. Geburstag (Zweiter Band: Staats- und Verfassungsrecht), Tübingen, J. C. B. Mohr (Paul Siebeck), p. 74; Garett, E., 1997, Who Directs Direct Democracy, The University of Chicago Law School Roundtable, Vol. 4, No. 1, p. 25.

21 Donovan, T., 2007, Direct Democracy as "super-precedent"?: Political Constraints of Citizen-Initiated Laws, Wilamette Law Review, Vol. 43, No. 1, p. 201.

22 Budge, I., 2006, Direct and Representative Democracy: Are They Necessarily Opposed?, Representation, Vol. 42, No. 1, pp. 1-12.

23 Schmitt famously criticized the majorities formed in voting processes, as in his view the secrecy of individual votes annulled their public significance. (Schmitt, C., 1954, Verfassungslehre, Berlin, Duncker \& Humblot, p. 245)

24 Brito Vieira, M., Runciman, D., 2008, Representation, Polity Press, Malden, p. 125. 
regulates the rules governing direct democracy, but may also be involved in constructing the identity of its subject. ${ }^{25}$

Direct democracy is also characterized by ideational forms of mediation in that the introduction and practice of its forms may be bound to some concepts. Chief among them, of course, is the idea of popular sovereignty. ${ }^{26}$ This concept may not only motivate the legislator to regulate direct democracy in a way that furthers a truly popular vote. Direct democracy is often considered to be an ideal expression of the sovereignty of the people, particularly if the people are empowered to decide on constitutional amendments. ${ }^{27}$ Indeed, due to the direct vote of the sovereign, direct democracy is said to produce a "surplus of legitimacy" 28 that may, according to defenders of de Gaulle's famous constitutional referendum of 1962 , subvert and dominate regular legal categories. ${ }^{29}$ As popular sovereignty is never fully realized, but is instead tamed by constitutionalism, ${ }^{30}$ its ideal may motivate the overthrow of the regular state of things and a more or less radical application of forms of direct democracy. ${ }^{31}$ The interpretation of popular sovereignty, particularly if it is identified with a simplistic understanding of Rousseau's "general will"32 can thus empower an act of direct democracy, possibly with troubling consequences for constitutionalism. Most notably, such interpretations may further the image of direct democracy as an expression of a monolithic will that makes dissent and resistance irrelevant. ${ }^{33}$

Representation as a concept is not in itself recognized as a mediating factor in direct democracy. Instead, it is identified with representative democracy and squarely opposed to direct democracy which, again, is

25 Baer, S., 2006, “Der Bürger” im Verwaltungsrecht. Subjektkonstruktion durch Leitbilder vom Staat, Mohr Siebeck, Tübingen, particularly pp. 34-42.

26 Mathieu, B., 2017, Le droit contre la démocratie?, L.G.D.J. - Lextenso, Paris, p. 289.

27 Oeter, S., Souveränität und Legitimation staatlicher Herrschaft in europäischen Mehrebenensystem, in: Epiney, A., Siegwart, K. (eds.), 1997, Direkte Demokratie und Europäische Union. Democracie directe et Union européenne, Freiburg, Universitätsverlag Freiburg Schweiz, pp. 30-31.

28 Böckenförde, E.-W., 1985, Democrazia e rappresentanza, Quaderni costituzionali, Vol. 5, No. 2, p. 321.

29 Denquin, J.-M., 1976, Referendum et plebiscite. Essai de theorie generale, Paris, Librairie generale de droit et de jurisprudence, p. 293.

30 Sajó, A., Uitz, R., 2017, Constitution of Freedom. Introduction to Legal Constitutionalism, Oxford, Oxford University Press, p. 118.

31 Daly, E., 2020, p. 6.

32 Bates, D., 2011, States of War. Enlightenment Origins of the Political, Columbia University Press, New York, p. 173.

33 Freeden, M., 2017, After the Brexit referendum: revisiting populism as an ideology, Journal of Political Ideologies, Vol. 22, No. 1, p. 7. 
defined by its adherence to a popular vote. On the other hand, of course, representative decision-making is done by representatives. ${ }^{34}$ The divide between representation and direct decision-making is then grounded in a polarity between presence of the people in direct democracy and their absence in representation. This correlates with Pitkin's well-known definition of representation as bringing into being that which is actually not present. ${ }^{35}$ Along the same vein, constitutional theorists argue that enabling direct democracy also makes possible a "presence" of the electorate that fills this absence. ${ }^{36}$ This locks representation out of consideration. In the well-rehearsed scenario, direct democracy is for the most part an ideal sidelined by representative democracy ${ }^{37}$ and in practice appears as an exception. Representation is identified with representative democracy and is considered to be a more or less separate whole. ${ }^{38}$

It should be noted that contemporary political theory rejects this old opposition between "absence" of representation and "presence" of direct democracy, relied upon in constitutional theory. It is now forcefully argued that representation is precisely what makes "the people" politically present. ${ }^{39}$ Representation is considered to create a gap between those who are represented and those who represent, a relationship that allows the political presence of the people through its representatives and is a two-way street. ${ }^{40}$ Representatives may be creative in representing the electorate and the electorate is free to criticize their work and challenge the representations provided. ${ }^{41}$ This, in turn, enables democratic contestation. In this

34 Presno Linera, M. Á., La democracia directa y la falacia de sus riesgos, in: Gutiérrez Gutiérrez, I. (ed.), 2014, La democracia indignada. Tensiones entre voluntad popular y representación politica, Granada, Comares, p. 65.

35 Pitkin, H., 1967, The Concept of Representation, Berkeley, University of California Press, pp. 8-9. See also Schmitt, C., 1954, pp. 204-208.

36 Suksi, M., 1993, pp. 18-19; Schott, S., 2012, L'initiative populaire dans les États fédérés allemande: Contribution á la connaissance d'une institution démocratique, Paris, L.G.D.J., p. 245; Taillon, P., 2012, Le referendum expression directe de la souveraineté du people? Essai critique sur la rationalisation de l'expression référendaire en droit comparé, Paris, Dalloz, pp. 2-3.

37 Loewenstein, K., 1964, Volk und Parlament. Nach der Staatstheorie der französischen Nationalversammlung von 1789. Studien zur Dogmengeschichte der Unmittelbaren Volksgesetzgebung, Aalen, Scientia Verlag, p. XXII.

38 Aragón Reyes, M., Planeamiento general: Partidos politicos y democracia directa, in: Biglino Campos, P. (ed.), 2016, Partidos politicas y mediaciones de la democracia directa, Madrid, Centro de estudios politicos y constitucionales, p. 21.

39 Plotke, D., 1997, Representation Is Democracy, Constellations, Vol. 1, No. 1, pp. 19, 27.

40 Urbinati, N., 2006, Representative Democracy. Principles and Genealogy, Chicago, The University of Chicago Press, pp. 224-225.

41 Runciman, D., 2007, The Paradox of Political Representation, The Journal of Political Philosophy, Vol. 15, No. 1, p. 94. 
light, direct democracy should not be considered a form of "presence" opposed to "absence", but an instrument that participates in clashes between different forms of presence.

The banishment of representation is not only unrealistic and outdated in light of what I have previously argued, but it eases the capture of a popular vote by different actors. ${ }^{42}$ Direct democracy in this light is a mere vote that decides a particular matter, dangerous unless prefaced by sufficient safeguards and empty of any content besides a popular majority for or against an outcome. Its temporality ends with the vote. Nonetheless, this decision has to be carried out in its context, which is always dominated by representation and which may provide a reinterpretation of the vote. For the decision to be used in this manner is unexceptional, as the episodic and narrow character of direct decision-making leaves a space for downplaying its impact or extoling it as an expression of the sovereign. What is problematic is that constitutional theory does not have a vocabulary that can map how, rather than being empty of representation, direct democracy serves as an arena for its different forms. Acknowledging this, by consequence, would provide the forms of direct democracy substance that they currently lack and would allow theorists to advance their understanding of their origins and effect. In the next part of this paper, I want to set the stage for such an understanding.

\section{Substance of Direct Democracy: How May the People Be?}

As I have argued, standard accounts of direct democracy depict it as an episodic decision-making mechanism devoid of any content other than its ephemeral subject matter. In this light, forms of direct democracy arise in relation to a specific issue and formally cease once a decision on it has been reached. ${ }^{43}$ The decision is made by an electorate and it is in this direct vote on an issue that its power is exhausted. If organized well, the result of the vote will be reflected in its political context and the power of government will once again be exercised solely by elected representatives.

In order to challenge the conventional wisdom, I want to look at the temporary space generated by forms of direct democracy from a different perspective. To do so, I will attempt to pose a different question to the

42 See, for instance, Castello, J. E., 1986, The Limits of Popular Sovereignty: Using the Initiative Power to Control Legislative Procedure, California Law Review, Vol. 74, No.

2, pp. 491-563.

43 Biglino P., Introducción, in: Biglino Campos, P. (ed.), 2016, p. 15. 
central subject of the procedure, "the people". Scholars exploring its place in direct democracy normally examine it to tackle a difficult problem of who "the people" are, both in terms of membership and the territory they inhabit. ${ }^{44}$ To ask this question is to investigate the possible author of a decision that is at the core of an instance of direct democracy. A different dimension of the problem may be brought to light if one asks what are the ways in which an act of direct democracy brings the people into existence. In other words, what are the qualities of "the people" made manifest through an instrument of direct democracy and how do they interact with other forms of popular presence, most notably representative democracy, but also spaces where the people are said to be normally absent? Here I want only to sketch a preliminary answer to this broad question.

Posing this question means that attention is diverted from the topic of an instance of direct democracy and a decision on it. Instead, we are interested in how creation of the people contained within an act of direct democracy draws from its context. ${ }^{45}$ A popular sovereign invoked through direct democracy is the creature of a question posed before it. The voice of the people, as has already been noted, speaks in accordance with what is required of it. ${ }^{46}$ It is the question, the topic of an act of direct democracy, that enables the people to exist in relation to it. The question then both summons the people and brings it into an interaction with its surroundings. This also means that the people created in an act of direct democracy are a representation, not in the sense of representative democracy, but in a sense of being a constructed image of what the people may be. By its presence, this vision of the people also places in sharp relief its alternatives.

Take for example the controversy concerning the existence of the Bavarian Senate. The Senate was an upper house of the Bavarian parliament, organized along corporativist lines, that had a primarily advisory capacity and a limited power to veto legislation adopted in the lower house. Even though bodies such as the Senate were not uncommon before the Second

44 Tierney, S., 2012, pp. 58-97.

45 This also allows us to to have a more fine-grained view of how direct democracy interacts with existing forms of political power, most notably those deployed within regular political processes. To ask how may the people politically exist is to inquire into the context that makes its presence possible and to draw from this context is to enable a discussion on how a form of direct democracy fits into it. By expanding on this, which is beyond the scope of this paper, it would be possible to develop a more extensive discussion of how direct democracy may be used and abused in regular political processes.

46 Böckenförde, E.-W., 2000, Estudios sobre el Estado de Derecho y la democracia, Madrid, Editorial Trotta, pp. 136-137. 
World War, ${ }^{47}$ the passage of time made it something of a curiosity and the subject of a citizens' initiative which, in 2000, abolished it.

Once the project of abolishing the Senate was raised through the citizens' initiative, a dispute over the standard of representation ensued, with opponents of the project making two arguments. The first argument was that the Senate cannot be abolished because its existence is a "fundamental democratic principle" protected by the eternity clause of the Bavarian Constitution. ${ }^{48}$ In the second place, a group of citizens made an argument from protecting the standard of participation in the Bavarian system of government. ${ }^{49}$ Simply put, they argued that the people's rule would be impaired if the Senate is removed from the Bavarian system of government. If either of the objections had been accepted, which was not the case, the constitutional amendment would be unconstitutional.

While the central issue of the dispute was clearly the removal of a body of government, the standards of political existence of the people were the underlying issue upon which the resolution of the central dispute rested. On the one hand was the idea that some forms of political presence are essential to Bavaria and thus incompatible with the representation of the people in the initiative. The features of the people's presence were in this sense considered to be fixed by the constitution. Additionally, it was claimed that the ephemeral sovereign contained in the initiative cannot be a match for an ongoing deliberative process offered by the Senate. In sum, at dispute was the way an act of direct democracy represented the people.

Note that both objections to abolishing the Bavarian Senate share the same logic. Both are efforts to challenge the initiative's definition of an underlying standard of representation, one that imagines that it is possible to represent "the people" without an upper house. Hence, it is this image of the popular sovereign that is embodied in the initiative and that forms its actual content. The decision on the Senate's existence hinged on whether such a vision could be overridden by a more powerful alternative.

An additional dimension of the representative work contained in this initiative is the clash between the quantitative and qualitative presence of the people. Whereas the opponents and proponents of the project exchanged arguments on the quality of representation, the Constitutional Court took the opportunity to find that no future constitutional amendment done via direct democracy is to be allowed unless at least $25 \%$ of

47 Holt, J. B., 1948, Corporative Occupational Organization and Democracy in Germany, Public Administration Review, Vol. 8, No. 1, pp. 38-39.

48 See the decision of the Bavarian Constitutional Court case Vf. 12-VIII-98, VF. 14-VII-98, Vf. 15-VII-98 of 17 September 1999 (hereinafter: Bavarian case), B.I.1.a), para. 3.

Bavarian case, B.I.2.d), B.I.2.e), t. B.I.3.b).bb). 
the total electorate accept the amendment, which, incidentally, was the threshold met by the initiative on abolishing the Senate. ${ }^{50}$ The quantitative standard was tied to its qualitative counterpart, as it was imposed due to the significance of the constitution as a fundamental document of the state, one that should not be changed by any ordinary majority.

The two elements of the presence of "the people", quantitative and qualitative, show how a decision reached in the ambit of direct democracy is not just an endpoint to a political controversy, but that it draws upon particular representations and works around their alternatives. The majority formed within its ambit cannot be considered a mere numerical construct, a majority that should simply overcome any legal and political barriers due to its sovereign status. Given that the majority is formed in relation to a specific issue, it is a limited construct that only temporarily displaces its alternatives, which other questions could have placed to the forefront.

Having in mind the double-layered tension between different qualitative visions of how the people may politically exist and between the qualitative and quantitative dimensions of this presence, it is evident that the specificity of direct democracy is not so much the direct decision of the people, but its power to bring to life conflicting alternatives of how the people may politically be. While some instead argue that referendums are an expression of the pre-existing "will of the people", 51 this wrongly ascribes to the popular sovereign an existence it does not have beyond the instruments of direct decision-making. ${ }^{52}$ The reality of direct democracy is conflict over representations of the people.

At issue then is how this conflict may be approached by constitutional theorists interested in direct democracy. My suggestion is that, rather than focusing on the divide between representation and direct democracy, with the concomitant expectation that forms of the latter may be completely tamed with appropriate legislation, we should think of representation as a category that breaches the divide and bridges different actors and decision-making processes. This would allow us to examine how the law does not only hinder or empower direct democracy in the abstract but may be used to instrumentalize it to bring to life specific understandings of representation. By consequence, this would also help in articulating what is, in the long-term, gained and lost by individual instances of direct

50 Bavarian case, para. II.2.f.1.

51 Taillon, P., 2012, pp. 28-31.

52 See, along the same lines, Mineur's criticism of the efforts to claim a greater degree of authenticity for some forms of representing "the people" over others. (Mineur, D., 2010, Archéologie de la représentation politique, Presses de Sciences Po, Paris.) 
democracy. After all, while standard accounts of individual acts of direct democracy are regularly restricted to considering details that may indeed be enlightening, ${ }^{53}$ the fact of the matter is that the citizenry exists beyond individual popular votes and lives with their consequences. In the next and final part of this paper, I use the concept of representation to develop a framework that may allow us to study direct democracy beyond the boundaries of a single vote.

\section{Framing the Substance of Representation: Arguments, Processes, Constructs}

What does it mean to think of representation as a category that transcends both the boundaries of representative and direct democracy as they are conventionally understood? The concept itself is not a barrier to this. As I have already noted, political theorists have extensively discussed what "representation" means in the abstract and at least two different meanings of the concept were identified in constitutional theory, representation as a shorthand for representative democracy and as the basic precondition for the existence and exercise of the state's powers. ${ }^{54}$ Additionally, legal scholars have noted that representation is an extraordinarily pliable notion that may be deployed as a rhetorical device and a justification for a change in the nature of the regime. ${ }^{55}$ Remember, for instance, that Sieyes used representation to argue that the Constituent Assembly is the bearer of pouvoir constituant and that this power generally cannot be deployed without representation. ${ }^{56}$ Representation is thus both a broad concept and a concept that can be used to construct political realities. It may be thought of as transcending the boundaries of representative democracy as it is normally understood in constitutional theory.

In order to identify forms of the broad concept of representation that are of use to examining direct democracy, we should consider the purposes

53 See, for instance, Ainis, M. (ed.), 2005, I referendum sulla fecondazione assistita, Milano, Giuffrè Editore; Ceccarini, L., 2017, Referendum on Renzi: The 2016 Vote on the Italian Constitutional Revision, South European Society and Politics, Vol. 22, No. 2, pp. 281-302.

54 Loughlin, M., Representation and Constitutional Theory, in: Craig, P., Rawlings, R. (eds.), 2003, Law and Administration in Europe. Essays in Honour of Carol Harlow, Oxford, Oxford University Press, pp. 47-49.

55 Brunet, P., 2004, Vouloir pour la nation. Le concept de representation dans la théorie de l'État, Montchrestien, Bruylant L.G.D.J.

56 Vatter, M., Poder constituyente y representación, in: Bustameante, G., Sazo, D. (eds.), 2016, Democracia y poder constituyente, Santiago, Fondo de Cultura Económica, pp. 73-92. 
of its different forms. As Daly argues, referendums, and indeed other forms of direct democracy, do not necessarily have to result in enacting a new piece of the law. Forms of direct decision-making may be deployed to express a political preference or to act as a kind of a symbolic speech. ${ }^{57}$ Many forms of direct democracy initiated in Croatia were really used as instruments of pressure. While they never resulted in actual referendums, they were successfully used to contest regular political processes. ${ }^{58}$ In Italy, legislation on the abrogative referendum, dedicated to abolishing laws, was not enacted for decades out of fear that the referendum would be used by the opposition. ${ }^{59}$ Thus, direct democracy may be used as an instrument of expression, contestation and, naturally, norm-creation.

With the functions of expression, contestation and norm-creation in mind, we can differentiate three forms of representation that may be deployed in regulating and in applying the instruments of direct democracy: representation as an argument, representation as a process, and representation as a construct. In what follows, I will take each of these in turn.

\subsection{REPRESENTATION AS AN ARGUMENT}

Representative democracy has at its core the practice of constructing and exchanging arguments. Representatives are expected to speak and act in the public interest and they are normally expected to do so in their own best judgment, a postulate that was famously worded by Burke. ${ }^{60}$ Arguments are thus the basic means through which the representatives bring "the people" into existence. However, given that there is a gap between representatives and those who are represented, arguments that are given in the name of the electorate need to be contestable if representation is to remain democratic. ${ }^{61}$ Indeed, the very identity of the represented is highly contestable, as the represented "people" is always at least partially an imaginary category to which the actual people need to be able to respond. ${ }^{62}$ This exchange is the core of representation.

57 Daly, E., 2020, p. 9.

58 Čepo, D., Nikić Čakar, D., 2019, Direct Democracy and the Rise of Political Entrepreneurs: An Analysis of Citizens' Initiative in Post-2010 Croatia, Anali Hrvatskog politološkog društva, Vol. 16, No. 1, pp. 27-48.

59 Rolla, G., Las dinámicas entre el referéndum, las instituciones de democracia representativa y los partidos politios. Consideraciones a la luz de la experiencia Italiana, in: Biglino Campos, P. (ed.), 2016, Partidos políticos y mediaciones de la democracia directa, Madrid, Centro de estudios políticos y constitucionales, p. 211.

60 Burke, E., Speech to the Electors of Bristol, (https://bit.ly/2aWmmgA).

61 Pitkin, H. F., 1967, p. 162.

62 Runciman, D., 2007, The Paradox of Political Representation, The Journal of Political Philosophy, Vol. 15, No. 1, p. 162; Thaa, W., 2016, Issues and Images - new sources of 
While direct democracy is normally seen as a collection of decision-making processes, its various forms are both a site for argument-making and an instrument of expressing a particular argument concerning representation. There are two central forums for arguments on representation within an instrument of direct democracy, the campaign preceding a vote, which may include signature gathering in the case of a citizens' initiative, and the act of voting itself.

As an instrument of expression, an executed instance of direct democracy may communicate an argument concerning representation in the outcome of the procedure, but it may also reinforce a particular understanding of the political quality of "the people" that may be conveyed in the background of the decision on the issue. The two need not converge. In the case of a referendum on Cyrillic script in Croatia, for instance, the Constitutional Court found that the electorate may not be asked to arbitrarily amend the law on national minority rights, effectively prohibiting plaques on Cyrillic script, used by the Serbian minority, from being placed on buildings of public administration institutions in units of local-self-government. Nonetheless, the decision did not include an outright dismissal of the relevance of war-related sentiments in Vukovar, a city in which the controversy regarding the Cyrllic script started. ${ }^{63}$ As a result, while the argument from representing a thick Croatian national identity was not explicitly transformed into positive law, the underlying ethnocentric sentiment remained and is still the neuralgic point of Croatia's popular sovereign.

Instruments of direct democracy are characterized by a power asymmetry between individuals on the one hand and the collective they are entering into by exercising their right to vote. While it is unquestionable that the individual act of voting has expressive value in its own right, ${ }^{64}$ in direct democracy it is fused with an artificial collective assembled by the question placed before the electorate. In order for direct democracy to be successful, then, individual voters need to be merged with an answer to a question set before them. This effect may be countered by organizing a deliberative process that bridges the micro-publics, with a decisive impact on formulating the question set before the electorate, and the public at large, invited to vote for or against a particular outcome ${ }^{65}$ Furthermore,

inequality in current representative democracy, Critical Review of International Social and Political Theory, Vol. 19, No. 3, p. 362.

63 Decision of the Constitutional Court of the Republic of Croatia in case U-VIIR $-4640 / 2014$, para. 29.

64 Schuessler, A. A., Expressive Voting, Rationality and Society, https://doi.org/10.1177/ 104346300012001005.

65 Tierney, S., 2013, Using Electoral Law to Construct a Deliberative Referendum: Moving Beyond the Democratic Paradox, Election Law Journal: Rules, Politics, and Policy, Vol. 12, No. 4, pp. 1-17. 
individuals do not relinquish their freedom of expression and they may rely upon it in debates concerning an act of direct democracy as well. However, as a dominantly collective mode of expression, direct democracy relies on the creation of a collective that gains more significance than individual voices that comprise it.

As a category that appears in representative and direct democracy and thus transverses the boundaries of the two, representation as an argument poses one central problem, the issue of values and the law. Insofar as arguments from representation challenge the usual presence of the popular sovereign and are incorporated in changes to the law, one should investigate what are the values that are advanced in the legal and political response to these claims. Näsström argues that, where representative claims are raised beyond elections, it is the value of equality that should take precedence, as in a democracy all should have the same say on democratic matters. ${ }^{66}$ Projects contained in a form of direct democracy that move away from this foundational value can be said to be inimical to an equal playing field and may possibly inaugurate an unbalanced popular sovereign.

\subsection{REPRESENTATION AS A PROCESS}

As the central means of exercising political power, representation is also a specific political process whose constituent parts are regulated by law. Representatives need to be legitimated through this process and work within it in order to be said to "represent" the people. Were this not the case, we would continuously have to determine which form of representation is legitimate and may speak for "the people". Contemporary political orders thus establish representative processes which, while not the sole form of political engagement for the citizens, certainly plays a cardinal role in political decision-making. While relying only on representation as an argument would quickly diminish political equality, in that the factual power to formulate arguments form representation necessarily differs between political actors, ${ }^{67}$ representation as a process is meant to guarantee a framework for decision-making that guarantees freedom and equality.

The representative process in a narrow sense includes the process to elect the members of the legislature and the exercise of their mandate. Law scholars normally pay most attention to this understanding of

66 Näsström, S., 2015, Democratic Representation Beyond Election, Constellations, Vol. 22, No. 1, p. 7.

67 Thaa, W., 2016, p. 365. 
representation. ${ }^{68}$ While it may well be comforting to remain restricted only to this understanding of representation, realistically the process in a narrow sense remains affected by other structures. These structures may include those normally taken to be specific and isolated wholes, such as direct democracy, but also preconditions for an orderly representative process, such as freedom of expression. ${ }^{69}$ Once these broader structures are taken into account, it becomes relevant how the law regulates their interface and thus defines the flow of representation as a process.

Representation as an argument need not cohere with representation as a process. Even though representation may be regulated by law, it contains areas of dispute that may be consolidated or thrown into disarray by deploying different arguments concerning representation. Take for instance the central subject of elections, the demos, whose definition may be left vague ${ }^{70}$ precisely because it may be hammered out in political contestation. This political contestation, of course, may include forms of representation stemming in direct democratic procedures, particularly those that seek to remodel the representative process, such as de Gaulle's famous referendum of 1962 .

Insofar as representation is understood to be a process, direct democracy may also be said to be contained in a separate procedure. In this manner, it is possible to downplay the importance some political actors may seek to acquire by making an argument from representation and claiming that their vision of the people should take precedence. Such was the approach of Berlin's Constitutional Court, which chose to see the interaction between direct democracy and representation as two procedures that are not of equal weight. Representation in a narrow sense was taken to supersede direct democracy. ${ }^{71}$ Ordering the interaction between the latter

68 See, for example, Meyer, H., 1973, Wahlsystem und Verfassungsordnung. Bedeutung und Grenzen wahlsystematischer Gestaltung nach dem Grundgesetz, Frankfurt am Main, Alfred Metzner Verlag, p. 13.

69 In the American context, Meiklejohn is famous for championing the importance of freedom of expression for an orderly democratic proceess. (Meiklejohn, A., 1960, Political Freedom. The Constitutional Powers of the People, Harper \& Row, New York)

70 Schultz, D., 2014, Election Law and Democratic Theory, New York, Routledge, p. 84.

71 The decision of the Constitutional Court of Berlin in case 78/99 of 18 May 2000, ECLI:DE:VERFGBE:2000:0518.78.99.0A, para. 33. While it is normally the federal structure of judicial review that attracts the most attention of those studying German constitutional law, German states (Länder) have also established their own constitutional courts. Just as their federal counterpart performs the role of the "guardian" of the federal constitution, so do these state constitutional courts protect constitutions of individual states, in conformity with the federal constitution. They are empowered to interpret state constitutions and ensure their application within each individual state. (Arias Guedón, S., 2018, Las relaciones de las cúspides judiciales en los sistemas 
and the representative element in this sense may also reassert the divide between the two. The bridging of this divide may be achieved by insisting on arguments from representation, as was the case in a series of Croatian citizens' initiatives in which the Constitutional Court prevented a referendum from taking place because it found that the Croatian parliament had adopted the suggestion contained in the initiative. ${ }^{72}$

\subsection{REPRESENTATION AS A CONSTRUCT}

Finally, it is possible to envision representation as a construct. This corresponds to Pitkin's "standing for" representation, which is to be differentiated from the "acting for" representation. ${ }^{73}$ While representing through arguments and in processes involves actions of the representative and the represented, the "standing for" representation involves the creation of constructs that in some sense represents the people. In political theory, there are two forms of "standing for" representation, descriptive and symbolic. While descriptive representation serves as a reflection of the features of the represented,${ }^{74}$ symbolic representation is intended to recall a greater whole that surpasses the symbol, provoking a psychological, emotional response in its audience. ${ }^{75}$ In this sense, symbolic representation can be problematic in terms of democracy, as symbolic representation may exclude democratic contestation, given that the latter is not necessary for a symbol to function.

In the context of direct democracy and representation, constructs may be relevant in two regards. To begin with, the decision reached in direct democracy can itself be a representative construct in that it may be

federales: El caso alemán, Anuario de la Facultad de Derecho de la Universidad Autónoma de Madrid, Vol. 22, No. 1, pp. 192-193) It should be noted that the state constitutions differ substantially and are not mere replicas of the federal constitution, with the Berlin constitution being one of the more extensive ones. (Lorenz, Astrid, Reutter, Werner, Subconstitutionalism in a Multilayered System. A Comparative Analysis of Constitutional politics in the German Länder, Perspectives on Federalism, Centro studi sul federalism, (https://bit.ly/2KDibJz), p. 160) For a more extensive investigation of German subnational constitutionalism see Arias Guedón, S., 2016, Las Constituciones de los Länder de la República Federal de Alemania. Contenido, garantías y posición en el ordenamiento jurídico alemán, Madrid, Centro de Estudios Politicos y Constitucionales.

72 See the decision of the Constitutional Court of the Republic of Croatia in UVIIR-4696/2010 of 20 October 2010, Official Gazette, No. 119/10, para. 3.

73 Pitkin, H. F., 1967, pp. 60-111.

74 Iris Marion Young advocates this form of representation. (Ravlić, S., 2008, Dileme političkog predstavništva, Zagreb, Politička kultura, p. 149)

75 Bíba, J., 2015, Symbolic Representation and the Paradox of Responsive Performativity, Human Affairs, Vol. 25, No. 1, p. 156. 
understood as a milestone in the democratic life of a country that isolates its subject matter from further contestation. The Croatian referendum on the definition of marriage, carried out in 2013, entrenched the definition of marriage as a heterosexual union. While this definition is normally interpreted to reserve only the term "marriage" for heterosexual couples, rather than the rights pertaining to one's private life equally, ${ }^{76}$ some political actors have sought to argue for a more extensive interpretation of the new provision..$^{77}$ In this light, representation as a construct becomes a tool to further a specific image of "the people", to either describe its features or symbolize its presence, even beyond the referendum.

Other than being tied into a direct decision, constructs are regularly introduced into the constitution to signal the presence of a precommitment. Fundamental rights and values such as dignity are some examples of this. These and the content they symbolize may be used to interpret representation as a process or as an argument. They can be successfully used to diffuse particular interpretations of representation. Indeed, more broadly, any law can be construed as if it "stands for" the will of the majority and the constitution may be identified with the crystallization of the ever-elusive constituent power. Remember that the Bavarian Constitutional Court justified special procedural demands for constitution-making via a citizens' initiative precisely on this basis.

\section{ConClusion}

The idea that direct democracy may be studied as an intersection of different forms of representation, rather than an empty place filled by the presence of "the sovereign people" remains both comforting and discomforting. It is comforting insofar as it helps us identify conflicting understandings of representation and their interaction, thus allowing for a critique of the way direct democracy develops within specific contexts, beyond isolated popular votes. It is discomforting insofar as it does not provide fixed solutions. Instead, it is intended to map out a form of decision-making that is powerfully political and that may be deployed in order to use the law to construct and deconstruct visions of "the people".

76 Announcement of the Constitutional Court of the Republic of Croatia on the popular constitutional referendum on the definition of marriage, SuS-1/2013 of 14 November 2013, Official Gazette, No. 138/13, para. 11.

77 Petričušić, A., 2015, Religiopolitics Through Law: Use of Legal Norms and Institutions by the Croatian Conservative Social Movement, Master's thesis, Central European University - Department of Sociology and Social Anthropology, Budapest, (http:// bit.ly/2n2evHr), p. 49. 
Further research is required to investigate how this matrix may be applied to different contexts.

\section{BIBLIOGRAPHY}

1. Ainis, M. (ed.), 2005, I referendum sulla fecondazione assistita, Milano, Giuffrè Editore.

2. Arias Guedón, S., 2016, Las Constituciones de los Länder de la República Federal de Alemania. Contenido, garantías y posición en el ordenamiento jurídico alemán, Madrid, Centro de Estudios Politicos y Constitucionales.

3. Arias Guedón, S., 2018, Las relaciones de las cúspides judiciales en los sistemas federales: El caso alemán, Anuario de la Facultad de Derecho de la Universidad Autónoma de Madrid, Vol. 22, No. 1.

4. Baer, S., 2006, „Der Bürger“ im Verwaltungsrecht. Subjektkonstruktion durch Leitbilder vom Staat, Mohr Siebeck, Tübingen.

5. Bates, D., 2011, States of War. Enlightenment Origins of the Political, Columbia University Press, New York.

6. Bíba, J., 2015, Symbolic Representation and the Paradox of Responsive Performativity, Human Affairs, Vol. 25, No. 1.

7. Biglino P., Introducción, in: Biglino Campos, P. (ed.), 2016, Partidos políticos y mediaciones de la democracia directa, Madrid, Centro de estudios políticos y constitucionales.

8. Böckenförde, E.-W., 1985, Democrazia e rappresentanza, Quaderni costituzionali, Vol. 5, No. 2.

9. Böckenförde, E.-W., 2000, Estudios sobre el Estado de Derecho y la democracia, Madrid, Editorial Trotta.

10. Brito Vieira, M., Runciman, D., 2008, Representation, Polity Press, Malden.

11. Brunet, P., 2004, Vouloir pour la nation. Le concept de representation dans la théorie de l'État, Montchrestien, Bruylant L.G.D.J.

12. Budge, I., 2006, Direct and Representative Democracy: Are They Necessarily Opposed?, Representation, Vol. 42, No. 1.

13. Castello, J. E., 1986, The Limits of Popular Sovereignty: Using the Initiative Power to Control Legislative Procedure, California Law Review, Vol. 74, No. 2.

14. Ceccarini, L., 2017, Referendum on Renzi: The 2016 Vote on the Italian Constitutional Revision, South European Society and Politics, Vol. 22, No. 2.

15. Colón-Ríos, J. I., 2012, Weak Constitutionalism. Democratic Legitimacy and the Question of Constituent Power, New York, Routledge.

16. Contiades, X., Fotiadou, A. (eds.), 2016, Participatory Constitutional Change. The People as Amenders of the Constitution, Routledge, New York.

17. Čepo, D., Nikić Čakar, D., 2019, Direct Democracy and the Rise of Political Entrepreneurs: An Analysis of Citizens' Initiative in Post-2010 Croatia, Anali Hrvatskog politološkog društva, Vol. 16, No. 1. 
18. Daly, E., 2020, Constitutionalism and crisis narratives in post-Brexit politics, Political Studies, https://doi.org/10.1177/0032321720904936m.

19. Daly, E., 2019, Translating Popular Sovereignty and Unfettered Constitutional Amendability, European Constitutional Law Review, Vol. 15, No. 4.

20. Denquin, J.-M., 1976, Referendum et plebiscite. Essai de theorie generale, Paris, Librairie generale de droit et de jurisprudence.

21. Donovan, T., 2007, Direct Democracy as „super-precedent“?: Political Constraints of Citizen-Initiated Laws, Wilamette Law Review, Vol. 43, No. 1.

22. Freeden, M., 2017, After the Brexit Referendum: Revisiting Populism as an Ideology, Journal of Political Ideologies, Vol. 22, No. 1.

23. Garett, E., 1997, Who Directs Direct Democracy, The University of Chicago Law School Roundtable, Vol. 4, No. 1.

24. Noyes, H., 2014, The Law of Direct Democracy, Durham, Carolina Academic Press.

25. El-Wakil, Alice, McKay, S., 2019, Disentangling Referendums and Direct Democracy: A Defence of the Systematic Approach to Popular Vote Processes, Representation - Journal of Representative Democracy, (https://www.tandfonline.com/ doi/full/10.1080/00344893.2019.1652203).

26. Hamon, F., 2012, Le referendum. Étude comparative, Paris, L.G.D.J.

27. Holt, J. B., 1948, Corporative Occupational Organization and Democracy in Germany, Public Administration Review, Vol. 8, No. 1.

28. Jacobsohn, G., Schor, M., Introduction: The Comparative Turn in Constitutional Theory, in: Jacobsohn, G., Schor, M. (eds.), 2018, Comparative Constitutional Theory, Cheltenham, Edward Elgar Publishing.

29. Krbek, I., Repräsentation nach der Doktrin der Volkssouveränität, in: Bracher, K. D. et al. (eds.), 1966, Die moderne Demokratie und ihr Recht. Festschrift für Gerhard Leibholz zum 65. Geburstag (Zweiter Band: Staats- und Verfassungsrecht), Tübingen, J. C. B. Mohr (Paul Siebeck).

30. Linz, J., 1998, Democracy's Time Constraints, International Political Science Review, Vol. 19, No. 1.

31. Loewenstein, K., 1964, Volk und Parlament. Nach der Staatstheorie der französischen Nationalversammlung von 1789. Studien zur Dogmengeschichte der Unmittelbaren Volksgesetzgebung, Aalen, Scientia Verlag.

32. Loughlin, M., Representation and Constitutional Theory, in: Craig, P., Rawlings, R. (eds.), 2003, Law and Administration in Europe. Essays in Honour of Carol Harlow, Oxford, Oxford University Press.

33. Mathieu, B., 2017, Le droit contre la démocratie?, L.G.D.J. - Lextenso, Paris.

34. Meiklejohn, A., 1960, Political Freedom. The Constitutional Powers of the People, Harper \& Row, New York.

35. Meyer, H., 1973, Wahlsystem und Verfassungsordnung. Bedeutung und Grenzen wahlsystematischer Gestaltung nach dem Grundgesetz, Frankfurt am Main, Alfred Metzner Verlag.

36. Mineur, D., 2010, Archéologie de la représentation politique, Presses de Sciences Po, Paris. 
37. Möllers, C., 2012, Les Gardiennes d'une séparation: les constitutions comme instruments de protection des différences entre le droit et la politique, Jus politicum, Vol. 7, No. 1.

38. Morel, L., Referendum, in: Rosenfeld, M., Sajó, A. (eds.), 2012, The Oxford Handbook of Comparative Constitutional Law, Oxford, Oxford University Press.

39. Näsström, S., 2015, Democratic Representation Beyond Election, Constellations, Vol. 22, No. 1.

40. Oeter, S., Souveränität und Legitimation staatlicher Herrschaft in europäischen Mehrebenensystem, in: Epiney, A., Siegwart, K. (eds.), 1997, Direkte Demokratie und Europäische Union. Democracie directe et Union européenne, Freiburg, Universitätsverlag Freiburg Schweiz.

41. Oklopcic, Z., 2012, Constitutional (Re)Vision: Sovereign Peoples, New Constituent Powers, and the Formation of Constitutional Orders in the Balkans, Constellations, Vol. 19, No. 1.

42. Oklopcic, Zoran, 2012, Independence Referendums and Democratic Theory in Quebec and Montenegro, Nationalism and Ethnic Politics, Vol. 18, No. 1.

43. Petričušić, A., 2015, Religiopolitics Through Law: Use of Legal Norms and Institutions by the Croatian Conservative Social Movement, Master's thesis, Central European University - Department of Sociology and Social Anthropology, Budapest, (http://bit.ly/2n2evHr).

44. Rolla, G., Las dinámicas entre el referéndum, las instituciones de democracia representativa y los partidos politios. Consideraciones a la luz de la experiencia Italiana, in: Biglino Campos, P. (ed.), 2016, Partidos políticos y mediaciones de la democracia directa, Madrid, Centro de estudios políticos y constitucionales.

45. Pitkin, H., 1967, The Concept of Representation, Berkeley, University of California Press.

46. Plotke, D., 1997, Representation Is Democracy, Constellations, Vol. 1, No. 1.

47. Presno Linera, M. Á., La democracia directa y la falacia de sus riesgos, in: Gutiérrez Gutiérrez, I. (ed.), 2014, La democracia indignada. Tensiones entre voluntad popular y representación politica, Granada, Comares.

48. Ravlić, S., 2008, Dileme političkog predstavništva, Zagreb, Politička kultura.

49. Reeves, M., 2016, Democracy on Speed, Social Anthropology, Vol. 24, No. 4,

50. Reyes, M. A., Planeamiento general: Partidos politicos y democracia directa, in: Biglino Campos, P. (ed.), 2016, Partidos politicas y mediaciones de la democracia directa, Madrid, Centro de estudios politicos y constitucionales.

51. Roznai, Y., 2018, The Newest-Oldest Separation of Powers, European Constitutional Law Review, Vol. 14, No. 4.

52. Runciman, D., 2007, The Paradox of Political Representation, The Journal of Political Philosophy, Vol. 15, No. 1.

53. Sajó, A., Uitz, R., 2017, Constitution of Freedom. Introduction to Legal Constitutionalism, Oxford, Oxford University Press.

54. Schmitt, C., 1954, Verfassungslehre, Berlin, Duncker \& Humblot.

55. Schmitt, C., 2014, Volksentscheid und Volksbegehren. Ein Beitrag zur Auslegung der Weimarer Verfassung und zur Lehre von der unmittelbaren Demokratie, Berlin, Duncker \& Humblot. 
56. Schott, S., 2012, L'initiative populaire dans les États fédérés allemande: Contribution á la connaissance d'une institution démocratique, Paris, L.G.D.J.

57. Schuessler, A. A., Expressive Voting, Rationality and Society, (https://doi. org/10.1177/104346300012001005)

58. Schultz, D., 2014, Election Law and Democratic Theory, New York, Routledge.

59. Suksi, M., 1993, Bringing in the People. A Comparison of Constitutional Forms and Practices of the Referendum, Dordrecht, Martinus Nijhoff Publishers.

60. Taillon, P., 2012, Le referendum expression directe de la souveraineté du people? Essai critique sur la rationalisation de l'expression référendaire en droit comparé, Paris, Dalloz.

61. Thaa, W., 2016, Issues and Images - New Sources of Inequality in Current Representative Democracy, Critical Review of International Social and Political Theory, Vol. 19, No. 3.

62. Tierney, S., 2012, Constitutional Referendums: The Theory and Practice of Republican Deliberation, Oxford, Oxford University Press.

63. Tierney, S., The Scottish Independence Referendum: A Model of Good Practice in Direct Democracy?, in: Ruth-Lovell, S. P., Welp, Y., Whitehead, L. (eds.), 2017, Let the People Rule? Direct Democracy in the Twenty-First Century, Colchester, ECPR Press.

64. Tierney, S., 2013, Using Electoral Law to Construct a Deliberative Referendum: Moving Beyond the Democratic Paradox, Election Law Journal: Rules, Politics, and Policy, Vol. 12, No. 4.

65. Trueblood, Leah, The Uses and Abuses of Referendums, doctoral thesis, University of Oxford - Trinity College, (https://ethos.bl.uk/OrderDetails.do?uin=uk. bl.ethos.770425).

66. Urbinati, N., 2006, Representative Democracy. Principles and Genealogy, Chicago, The University of Chicago Press.

67. Vatter, M., Poder constituyente y representación, in: Bustameante, G., Sazo, D. (eds.), 2016, Democracia y poder constituyente, Santiago, Fondo de Cultura Económica.

\section{Case LaW}

1. Bavarian Constitutional Court case Vf. 12-VIII-98, VF. 14-VII-98, Vf. 15-VII-98 of 17 September 1999.

2. Constitutional Court of Berlin case 78/99 of 18 May 2000, ECLI:DE:VERFGBE:2 000:0518.78.99.0A.

3. Announcement of the Constitutional Court of the Republic of Croatia on the popular constitutional referendum on the definition of marriage, SuS-1/2013 of 14 November 2013, Official Gazette, No. 138/13.

4. Constitutional Court of the Republic of Croatia in U-VIIR-4696/2010 of 20 October 2010, Official Gazette, No. 119/10.

5. Constitutional Court of the Republic of Croatia case U-VIIR-4640/2014. 


\title{
INTERNET SOURCES
}

1. Burke, E., Speech to the Electors of Bristol, (https://bit.ly/2aWmmgA).

2. Lorenz, A., Reutter, W., Subconstitutionalism in a Multilayered System. A Comparative Analysis of Constitutional Politics in the German Länder, Perspectives on Federalism, Centro studi sul federalism, (https://bit.ly/2KDibJz).

\section{KONCEPTUALIZIRANJE IZRAVNE DEMOKRACIJE KAO SJECIŠTA RAZLIČITIH OBLIKA PREDSTAVLJANJA}

\author{
Matija Miloš
}

\section{REZIME}

Izravna se demokracija, kao iznimni instrument suvremenih ustavnih demokracija, obično smatra odvojenom od one predstavničke. U ovom radu istražujem taj dobro utabani jaz, pitajući se kako se odnosi prema našem razumijevanju središnjeg subjekta izravne demokracije, narodu. Pokazujem kako teoretiziranje što za svoje polazište uzima dihotomiju između „odsutnosti“ i „prisutnosti“, a koja je vezana za odvojenost predstavljanja i oblika neposredne demokracije, ima vezu s poistovjećivanjem biračkog tijela i naroda. Nadalje, pokazujem kako je ovaj pristup nesposoban prikazati načine na koje predstavljanje naroda nastaje i biva instrumentalizirano u sklopu neposredne demokracije. U ovom radu dokazujem da je tom fenomenu moguće pristupiti ukoliko se neposredna demokracija promatra kao zapletena s predstavljanjem „naroda“, i to argumentima, procesima i konstruktima.

Ključne riječi: neposredna demokracija, referendum, predstavnička demokracija, predstavljanje, ustavna teorija.

Article History:

Received: 11 April 2020

Accepted: 22 May 2020 